\title{
Fibrinogen-Fibrin Degradation Product Levels in Different Types of Intravascular Haemolysis
}

\author{
S. D. SLATER, C. R. M. PRENTICE, W. H. BAIN, J. D. BRIGGS
}

British Medical fournal, 1973, 3, 471-473

\section{Summary}

To examine the possibility that intravascular haemolysis may lead to intravascular coagulation we have compared the degree of fibrin deposition, as measured by levels of serum fibrinogen-fibrin degradation products (F.D.P.), in two difierent types of intravascular haemolysis associated with red cell fragmentation. F.D.P. levels in 56 patients with intravascular haemolysis secondary to prosthetic heart valves were compared with those in 18 patients who had microangiopathic haemolytic anaemia (M.H.A.) associated with malignant hypertension or renal disease. F.D.P. levels were raised in almost all the patients with M.H.A., and this group had significantly higher levels than any of the valve replacement groups. In contrast, in the prosthetic valve patients F.D.P. levels were usually normal and bore no relation to the degree of haemolysis. It is suggested that in the absence of other precipitating factors intravascular haemolysis will not initiate intravascular coagulation. In M.H.A., while the intravascular haemolysis appears to be a consequence of an underlying intravascular coagulation, it is likely that persistence of the coagulation disturbance is related more to factors such as small vessel damage than to the release of any thromboplastic substances from fragmented red cells.

\section{Introduction}

Disseminated intravascular coagulation may complicate a variety of disorders, such as disseminated malignancy, Gramnegative septicaemia, amniotic fluid embolus, retained dead fetus, snake bite, and shock, and the subject has been extensively reviewed (Verstraete et al., 1965; Hardaway, 1966; Merskey et al., 1967; Thrombosis et Diathesis Haemorrhagica, 1969; Pitney, 1971; Simpson and Stalker, 1973). It may be associated with an increase of serum fibrinogen-fibrin degradation products (F.D.P.) due probably to secondary fibrinolytic action (Merskey et al., 1966, 1967). High F.D.P. levels may also be found in some patients with renal or other disease associated with more-localized intravascular fibrin deposition (Nilsson, 1971; Briggs et al., 1972; Lancet, 1972). In these conditions there is often red cell fragmentation with haemolysis, termed microangiopathic haemolytic anaemia (M.H.A.), which is thought to be secondary to trauma to red cells as they pass through small arterioles partially blocked by fibrin (Brain et al., 1962; Bull et al., 1968; Rubenberg et al., 1968; Brain, 1972).

Royal Infirmary, Glasgow

S. D. SLATER, M.B., M.R.C.P., Registrar in Haematology (Present appointment: Senior Registrar in Medicine, Southern General Hospital, Glasgow S.W.i).

C. R. M. PRENTICE, M.D., M.R.C.P., Wellcome Senior Clinical Research

Fellow and Consultant Physician

W. H. BAIN, cH.M., F.R.C.s., Consultant Cardiac Surgeon

Weatern Infirmary, Glasgow G11 6NT

J. D. BRIGGS, M.B., F.R.C.P., Consultant Physician in Renal Diseases
It has been suggested that intravascular haemolysis may potentiate intravascular coagulation and establish a vicious cycle of recurrent fibrin deposition in small vessels (Brain, 1968; Rubenberg et al., 1968; Linton et al., 1969).

To study the role of intravascular haemolysis in the pathogenesis of intravascular coagulation we have compared F.D.P. concentrations in two different types of disorder in which intravascular haemolysis with red cell fragmentation occurs. The first group comprised patients with M.H.A. associated with renal disease, many of whom had malignant hypertension. In this group the red cell fragmentation probably results from intravascular fibrin deposition within damaged small vessels (Brain et al., 1962; Bull et al., 1968; Rubenberg et al., 1968; Brain, 1972). The second group were patients with cardiac ball-valve prostheses in whom intravascular haemolysis is a common complication (Andersen et al., 1965; Marsh and Lewis, 1969; Slater and Fell, 1972). In these patients the trauma to the red cells occurs at the valve replacement site.

\section{Patients and Methods}

Fifty-six patients with ball and cage Starr-Edwards cardiac valve prostheses were studied ( 27 men and 29 women; mean age 41 years, range 27-55 years). There were 22 cases of aortic valve replacement, 29 of mitral valve replacement, and 5 of aortic plus mitral valve replacement. In most cases the cloth-covered cage and metal ball type of prosthesis, models 2300 (aortic) and 6300 (mitral), had been used. The operations had been performed 3 to 73 months previously, all but eight having been done within the previous 36 months. The patients were selected at random from those with prosthetic valves attending the anticoagulant clinics, and all were receiving long-term warfarin therapy. Full blood counts, blood film examinations, urinary haemosiderin tests, and ${ }^{51} \mathrm{Cr}$ erythrocyte survival studies were carried out as described by Slater and Fell (1972). Blood samples for F.D.P. measurement were collected in $0.04 \%$ tranexamic acid and allowed to clot for four hours at room temperature before separation of the serum. F.D.P. levels were estimated by the tanned red cell haemagglutination inhibition immunoassay of Merskey et al. (1966); the upper limit of normal was $5 \mu \mathrm{g} / \mathrm{ml}$.

The patients with valve prostheses were subdivided according to the estimated degree of intravascular haemolysis, as follows: grade 0 (17 patients)-no haemosiderinuria, red cell fragmentation, or anaemia (that is, no evidence of haemolysis); grade 1 (23 patients)-persistent haemosiderinuria without red cell fragmentation or anaemia; grade 2 ( 9 patients)-haemosiderinuria plus red cell fragmentation but no anaemia; grade 3 (7 patients)-haemosiderinuria, red cell fragmentation, and anaemia present. The severity of red cell fragmentation was assessed semiquantitatively and was classified from 0 to 3, 0 being a blood film with no fragmentation and 3 one with the greatest numbers of red cell fragments (corresponding to about $3 \%$ or more of the red blood cells).

The 18 patients with M.H.A. associated with renal disease, 10 of whom had malignant hypertension, were described previously in a study of F.D.P. levels in renal disease (Briggs et al., 1972).

Statistical analysis was carried out by the $x^{2}$ method in which the number of normal and raised serum F.D.P. levels in the various groups were compared. 


\section{Results}

The serum F.D.P. levels in the different haemolytic grades in the prosthetic valve patients are shown in fig. 1 compared with the levels obtained in the patients with M.H.A. In only a few valve patients were raised F.D.P. levels found and there were no significant differences in the incidence of high F.D.P. values between the four haemolytic grades $(P>0.2)$. Full details of

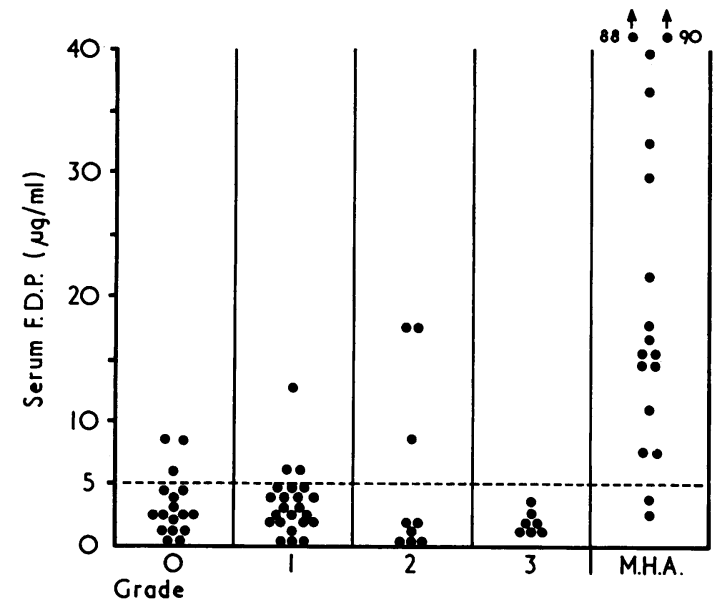

FIG. 1-Serum F.D.P. levels in different haemolytic grades of prosthetic valve patients and in patients with M.H.A.

the investigations in the seven patients in grade 3, none of whom had abnormal F.D.P. levels, are given in table I. In contrast the incidence of increased F.D.P. levels in the M.H.A. group was significantly higher than in any of the valve replacement groups (M.H.A. v. haemolytic grades 0,1 , and 3, P $<0.001$; M.H.A. $v$. haemolytic grade $2,0.025>P>0.01$ ).

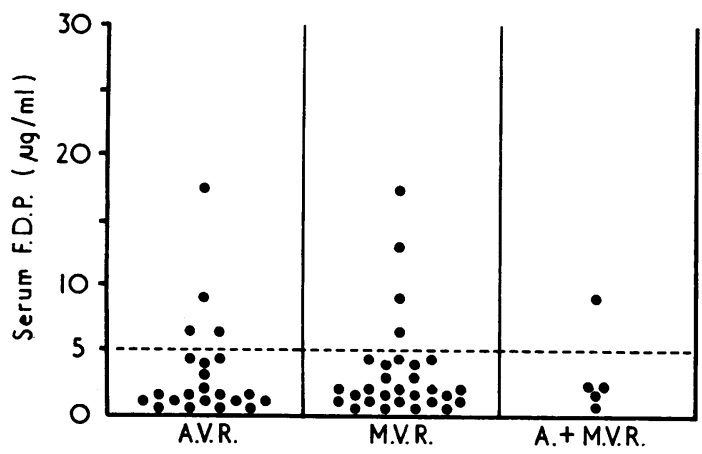

FIG. 2-Serum F.D.P. levels related to different valve replacement sites. A.V.R. = Aortic valve replacement. M.V.R. = Mitral valve replacement.
Serum F.D.P. levels related to the position of the prosthetic valve are shown in fig. 2. No significant differences in the incidence of raised F.D.P. levels were found between the different valve replacement sites $(P>0.5)$. By comparison the distribution of haemolytic grade according to valve site is shown in table II. It is seen that patients with an aortic valve replacement were associated with the more severe grades of haemolysis, whereas those with a mitral valve replacement were much less affected.

TABLE II-Distribution of Haemolytic Grades in Prosthetic Valve Patients

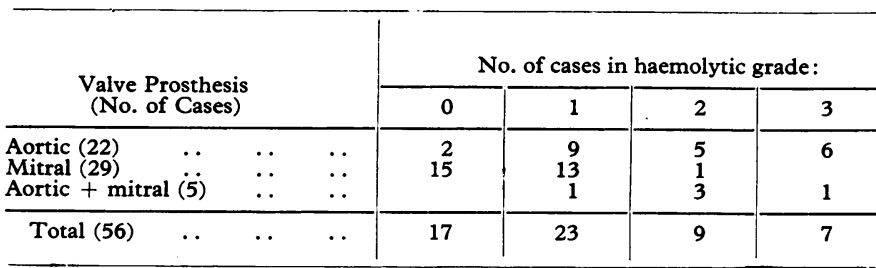

\section{Discussion}

Red cell haemolysate contains adenosine diphosphate (Gaardner et al., 1961), which is a powerful platelet aggregating agent (Mustard and Packham, 1970); it has thromboplastic activity (Quick et al., 1954), inhibits fibrinolysis (Blofield and Hawkey, 1967), and appears likely to have a physiological role in haemostasis (Pederson et al., 1967). It has been suggested, therefore, that intravascular haemolysis may be associated with a tendency to intravascular fibrin deposition. This mechanism may promote a vicious cycle of events in diseases primarily associated with intravascular coagulation (Brain, 1968; Rubenberg et al., 1968; Linton et al., 1969), and may be responsible for the thrombotic complications of paroxysmal nocturnal haemoglobinuria (Dacie, 1967). There is also clinical and experimental evidence that in conditions with slow capillary blood flow such as shock, intravascular haemolysis may be a cause rather than a sequel of disseminated intravascular coagulation (Hardaway, 1966).

In patients with prosthetic heart valves we have found no evidence that intravascular haemolysis has led to disseminated intravascular coagulation as detected by raised F.D.P. levels. No differences were found in the F.D.P. levels between those valve patients without haemolysis and those with the more severe grades of haemolysis. There was also no difference in the incidence of high F.D.P. levels between the valve replacement sites, whereas patients with an aortic prosthesis were more often and severely affected by haemolysis. These results are supported by reports of normal fibrinogen catabolism in patients with prosthetic heart valves (Baker et al., 1968; Harker and Slichter, 1970), and plasma fibrinogen levels may even be increased (Tessier et al., 1971). Nine of the 56 valve patients had raised F.D.P. levels, but repeat estimations performed in three of these cases gave normal results. The reason for these few

TABlE I-Details of Investigations in Prosthetic Valve Patients in Haemolytic Grade 3

\begin{tabular}{|c|c|c|c|c|c|c|c|c|c|}
\hline $\begin{array}{l}\text { Case } \\
\text { No. }\end{array}$ & Sex & $\begin{array}{c}\text { Valve } \\
\text { Prosthesis }\end{array}$ & $\begin{array}{c}\mathrm{Hb} \\
(\mathrm{g} / \mathbf{1 0 0} \mathrm{ml})\end{array}$ & $\begin{array}{l}\text { P.C.V. } \\
(\%)\end{array}$ & $\begin{array}{c}\text { Reticulocytes } \\
(\%)\end{array}$ & $\begin{array}{c}\text { Red Cell } \\
\text { Fragmentation } \\
\text { (Grade) }\end{array}$ & $\begin{array}{c}\text { Urinary } \\
\text { Haemosiderin }\end{array}$ & 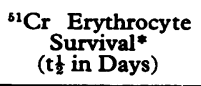 & $\begin{array}{l}\text { F.D.P. } \\
(\mu \mathrm{g} / \mathrm{ml})\end{array}$ \\
\hline $\begin{array}{l}1 \\
2 \\
3 \\
4 \\
5\end{array}$ & $\begin{array}{l}\mathbf{F} . \\
\mathbf{M} . \\
\mathbf{F} . \\
\mathbf{M} . \\
\mathbf{F} .\end{array}$ & $\begin{array}{l}\text { Aortic } \\
\text { Aortic } \\
\text { Aortic } \\
\text { Aortic } \\
\text { Aortic \& } \\
\text { mitral }\end{array}$ & $\begin{array}{r}7.5 \\
7.9 \\
9 \cdot 0 \\
10 \cdot 1 \\
10 \cdot 9\end{array}$ & $\begin{array}{l}22 \\
22 \\
27 \\
30 \\
32\end{array}$ & $\begin{array}{r}13 \\
9 \\
13 \\
9 \\
8\end{array}$ & $\begin{array}{l}3 \\
2 \\
3 \\
3 \\
3\end{array}$ & $\begin{array}{l}\text { Gross } \\
\text { Moderate } \\
\text { Gross } \\
\text { Gross } \\
\text { Gross }\end{array}$ & $\begin{array}{c}13 \cdot 5 \\
10 \\
9 \\
14 \\
14\end{array}$ & $\begin{array}{l}1.4 \\
2.7 \\
1.4 \\
2.7 \\
3.2\end{array}$ \\
\hline $\begin{array}{l}6 \\
7\end{array}$ & $\begin{array}{l}\text { M. } \\
\text { M. }\end{array}$ & $\begin{array}{l}\text { Aortic } \\
\text { Aortic }\end{array}$ & $\begin{array}{l}11 \cdot 2 \\
13 \cdot 3\end{array}$ & $\begin{array}{l}32 \\
39\end{array}$ & $\begin{array}{l}4 \\
5\end{array}$ & $\begin{array}{l}2 \\
1\end{array}$ & $\begin{array}{l}\text { Gross } \\
\text { Gross }\end{array}$ & $\stackrel{12}{\text { Not known }}$ & $\begin{array}{l}1.4 \\
2.8\end{array}$ \\
\hline
\end{tabular}

* Normal t $\frac{1}{2}=25-33$ days. 
abnormal F.D.P. levels is unknown; there was no clinical evidence to suggest that they may have been due to embolic episodes.

In contrast F.D.P. levels were raised in 16 of the 18 patients with M.H.A., a much higher incidence than in any of the valve replacement groups, though the degree of haemolysis in them was no more severe than in the valve patients in haemolytic grade 3.

We suggest that intravascular haemolysis with red cell fragmentation, in the absence of other precipitating factors, will not lead to intravascular coagulation; however, two qualifying statements should be made. Firstly, all the valve patients were taking warfarin, which may have diminished any tendency to form thrombi, though embolic complications of valve prostheses may occur despite well controlled anticoagulant therapy (Akbarian et al., 1968). These emboli originate at the valve site, where the concentration of red cell haemolysate may be high. No positive correlation, however, has been reported between the incidence of the haemolytic and thromboembolic complications of prosthetic cardiac valves. Secondly, since the red cell fragmentation in the valve patients occurs at the valve replacement site the thrombus-promoting factors released from the damaged red cells are likely to be diluted or inhibited in the fast flowing blood stream of the large arteries, and any tendency towards disseminated intravascular coagulation may be reduced.

These findings emphasize the significance of the coagulation disturbance in M.H.A., where raised F.D.P. levels are almost invariably present (Gavras et al., 1971; Briggs et al., 1972). Moreover, Oliver et al. (1973) have shown that patients with malignant hypertension have significantly raised F.D.P. levels, increased urokinase sensitivity, and lowered platelet counts even in the absence of overt M.H.A. The role of intravascular haemolysis in the potentiation of coagulation in patients with M.H.A. remains to be resolved. If intravascular haemolysis is of importance there must also be other factors, such as altered blood flow, which operate locally in small vessels, since haemolysis in large vessels appears not to result in fibrin deposition. F.D.P. levels in M.H.A. may be increased by mechanisms which are independent of any clot-promoting substances released from red cells and even of the thrombin-induced coagulation system. Charm and Wong (1970) showed in vitro that fibrinogen undergoes degradation due to shearing within the circulation. Increased shearing within damaged small vessels in patients with M.H.A. could result in accelerated fibrinogen degradation with the production of high serum F.D.P. levels.

In conclusion it is suggested that the intravascular release of red cell haemolysate by itself is not deleterious; its importance in the aggravation of a primary process of intravascular coagulation remains to be established.

We are grateful to Dr. G. A. McDonald for his interest in this study and to Mrs. C. Pidgeon for technical help. C.R.M.P. is in receipt of a grant from the Wellcome Trust.

Requests for reprints should be sent to Dr. S. D. Slater, Department of Medicine, Southern General Hospital, Govan Road, Glasgow S.W.1.

\section{References}

Akbarian, M., Austen, W. G., Yurchak, P. M., and Scannell, J. G. (1968). Circulation, 37, 826.

Andersen, M. N., Gabrieli, E., and Zizzi, J. A. (1965). Fournal of Thoracic and Cardiovascular Surgery, 50, 501.

Baker, L. R. I., Rubenberg, M. L., Dacie, J. V., and Brain, M. C. (1968). British fournal of Haematology, 14, 617

Blofield, A., and Hawkey, C. (1967). Lancet, 1, 852

Brain, M. C. (1968). Lancet, 2,1394

Brain, M. C. (1972). British Yournal of Haematology, 23, Suppl., p. 45.

Brain, M. C., Dacie, J. V., and Hourihane, D. O'B. (1962). British fournal of Haematology, 8, 358.

Briggs, J. D., Prentice, C. R. M., Hutton, M. M., Kennedy, A. C., and McNicol, G. P. (1972). British Medical fournal, $4,82$.

Bull, B.S., Rubenberg, M. L., Dacie, J. V., and Brain, M. C. (1968). British fournal of Haematology, 14, 643 .

Charm, S. E., and Wong, B. L. (1970). Science, 170, 466.

Dacie, J. V. (1967). Haemolytic Anaemias, part 4. London, Churchill

Gaardner, A., Jonsen, J., Laland, S., Hellem, A. J., and Owren, P. A. (1961). Nature, 192, 531 .

Gavras, H., et al. (1971). Circulation Research, 28, Suppl., No. 2, p. 127.

Hardaway, R. M. (1966). Syndromes of Disseminated Intravascular Coagulation, with Special Reference to Shock and Hemorrhage. Springfield, Thomas.

Harker, L. A., and Slichter, S. J. (1970). New England fournal of Medicine, 283,1302 .

Lancet, 1972, 2, 957.

Linton, A. L., et al. (1969). Lancet, 1, 1277.

Marsh, G. W., and Lewis, S. M. (1969). Seminars in Hematology, 6, 133.

Merskey, C., Kleiner, G. J., and Johnson, A. J. (1966). Blood, 28, 1

Merskey, C., Johnson, A. J., Kleiner, G. J., and Wohl, H. (1967). British Fournal of Haematology, 13, 528.

Mustard, J. F., and Packham, M. A. (1970). Pharmacological Reviews, 22, 97.

Nilsson, I. M. (1971). Scandinavian fournal of Haematology, Suppl. No. 13, p. 317.

Oliver, N., et al. (1973). Abstract, Proceedings of the British Cardiac Society, Glasgow.

Pederson, H. J., Tebo, T. H., and Johnson, S. A. (1967). American fournal of Clinical Pathology, 48, 62.

Pitney, W. R. (1971). Seminars in Hematology, 8, 65.

Quick, A. J., Georgatsos, J. G., and Hussey, C. V. (1954). American fournal of the Medical Sciences, $228,207$.

Rubenberg, M. L., Regoeczi, E., Bull, B. S., Dacie, J. V., and Brain, M. C. (1968). British fournal of Haematology, 14, 627.

Simpson, J. G., and Stalker, A. L. (1973). Clinics in Haematology, 2, 189. Slater, S. D., and Fell, G. S. (1972). Clinical Science, 42, 545.

Tessier, Y., Littleton, P., Collet, H., Marshall, J., and McDonald, L. (1971). Lancet, 1, 17.

Thrombosis et Diathesis Haemorrhagica, 1969, Suppl. No. 36.

Vesrtraete, M., Vermylen, C., Vermylen, J., and Vandenbroucke, J. (1965). American Fournal of Medicine, 38, 899 . 